\title{
Moisture source of precipitation in Western Dronning Maud Land, Antarctica
}

\author{
C.H. REIJMER ${ }^{\star}$ and M.R. VAN DEN BROEKE \\ Institute for Marine and Atmospheric Research, Utrecht University, PO Box 80005, 3508 TA Utrecht, The Netherlands \\ ${ }^{*}$ C.H.Reijmer@phys.uu.nl
}

\begin{abstract}
Moisture sources for snow falling in Dronning Maud Land (DML), Antarctica, are calculated for 1998 using three dimensional 5-days backward air parcel trajectories. The drilling site of the European Project on Ice Coring in Antarctica (EPICA) in DML is chosen as the main arrival point $\left(75.0^{\circ} \mathrm{S}, 0.01^{\circ} \mathrm{E}\right)$. A distinction is made between trajectories with and without snowfall at arrival. Of the snowfall trajectories, $40-80 \%$ are located in the Atlantic Ocean within four days before arrival. Evaporation along these trajectories is largest three to four days before arrival. The air parcels are then located between $40^{\circ}$ and $60^{\circ} \mathrm{S}$ in the Atlantic Ocean where surface temperatures range between $0^{\circ}$ and $20^{\circ} \mathrm{C}$. A case study for May 1998 shows that when snow falls exceptionally high temperatures and wind speeds prevail in the atmospheric boundary layer. The position of the trajectories in the boundary layer suggests a source region for this event between $40^{\circ}$ and $50^{\circ} \mathrm{S}$ and $20^{\circ}$ and $60^{\circ} \mathrm{W}$ in the Atlantic Ocean, where sea surface temperatures vary between $5^{\circ}$ and $15^{\circ} \mathrm{C}$.
\end{abstract}

Received 3 August 2000, accepted 22 December 2000

Key words: accumulation, Automatic Weather Stations, Dronning Maud Land, EPICA, moisture sources, trajectories

\section{Introduction}

Many deep ice cores have been drilled in the Antarctic and Greenland ice sheet, e.g. Vostok and Byrd (Antarctica), Greenland Ice Core Project (GRIP and North GRIP) and Greenland Ice Sheet Project (GISPII) (see e.g. Greenland Icecore Project (GRIP) Members (1993) and Petit et al. (1999)). The European Project on Ice Coring in Antarctica (EPICA) aims to drill a further two cores. The main objective of EPICA is to construct a high resolution climate record for the Antarctic and compare the results with other Antarctic and Greenland records.

The Atlantic Ocean is considered to be an important link between Antarctic and Greenland climate records (Stocker 1999). One of the EPICA cores will therefore be drilled in Dronning Maud Land (DML), an area of Antarctica bordering the Atlantic Ocean (Fig. 1). The relatively high accumulation rate at the selected drilling site, about $62 \mathrm{~mm}$ water equivalent per year (w.e. $\mathrm{yr}^{-1}$ ) (Oerter et al. 2000), makes it possible to obtain a detailed record of the last glacial-interglacial cycle.

The climate recorded in ice cores is mainly determined by the conditions in which snowfall occurs. This need not be representative for the mean conditions at that point (Noone \& Simmonds 1998, Noone et al. 1999). Several factors such as seasonality of snowfall and changes in moisture source regions (Jouzel et al. 1997) may bias the ice core record. The ratio of oxygen isotopes $\left(\delta^{18} \mathrm{O}\right)$ in the snow is often used to reconstruct temperature records from ice cores (Petit et al. 1999). However, $\delta^{18} \mathrm{O}$ in Antarctic snow represents a complex history of the moist parcel. It depends on the temperature of the ocean from which the moisture evaporated, the subsequent cycles of condensation and evaporation and the temperature at which the moisture finally condenses to form precipitation. This hampers the interpretation of the $\delta^{18} \mathrm{O}$ record. A change in $\delta^{18} \mathrm{O}$ could indeed reflect a realistic temperature change but could also be caused by a change in moisture source region or seasonality of the precipitation.

Several techniques have been used to trace moisture source regions of Antarctic snow. Petit et al. (1991) and Ciais et al. (1995) use deuterium excess as tracer in combination with idealized isotope models. They conclude that the Antarctic moisture has a subtropical origin, $30-40^{\circ} \mathrm{S}$ and $20-40^{\circ} \mathrm{S}$, respectively. Peixoto \& Oort (1992) came to the same conclusion on the basis of atmospheric water balance studies $\left(8-40^{\circ} \mathrm{S}\right.$ ). Other studies including $\delta^{18} \mathrm{O}$ (Bromwich \& Weaver 1983) and General Circulation Model (GCM) studies (Delaygue et al. 2000, Delmotte et al. 2000) suggest a more southern origin, $55-60^{\circ} \mathrm{S}$ and $30-60^{\circ} \mathrm{S}$, respectively. However, differences in source regions could be due to the differences in methods used, and do not necessarily contradict each other.

In this paper we use a combination of techniques to assess moisture sources for DML. To identify accumulation events we use data from nine Automatic Weather Stations (AWS) and we use a trajectory model to trace the moisture sources of the accumulation events. Using the trajectory method enables us to describe specific transport pathways in contrast with the GCM approach (e.g. Delaygue et al. (2000, Delmotte et al. (2000)), which only gives the location of the source region without an indication of the transport path or the air mass age. The approach in this paper is similar to the study of Noone et al. (1999), who use European Centre for Medium Range 


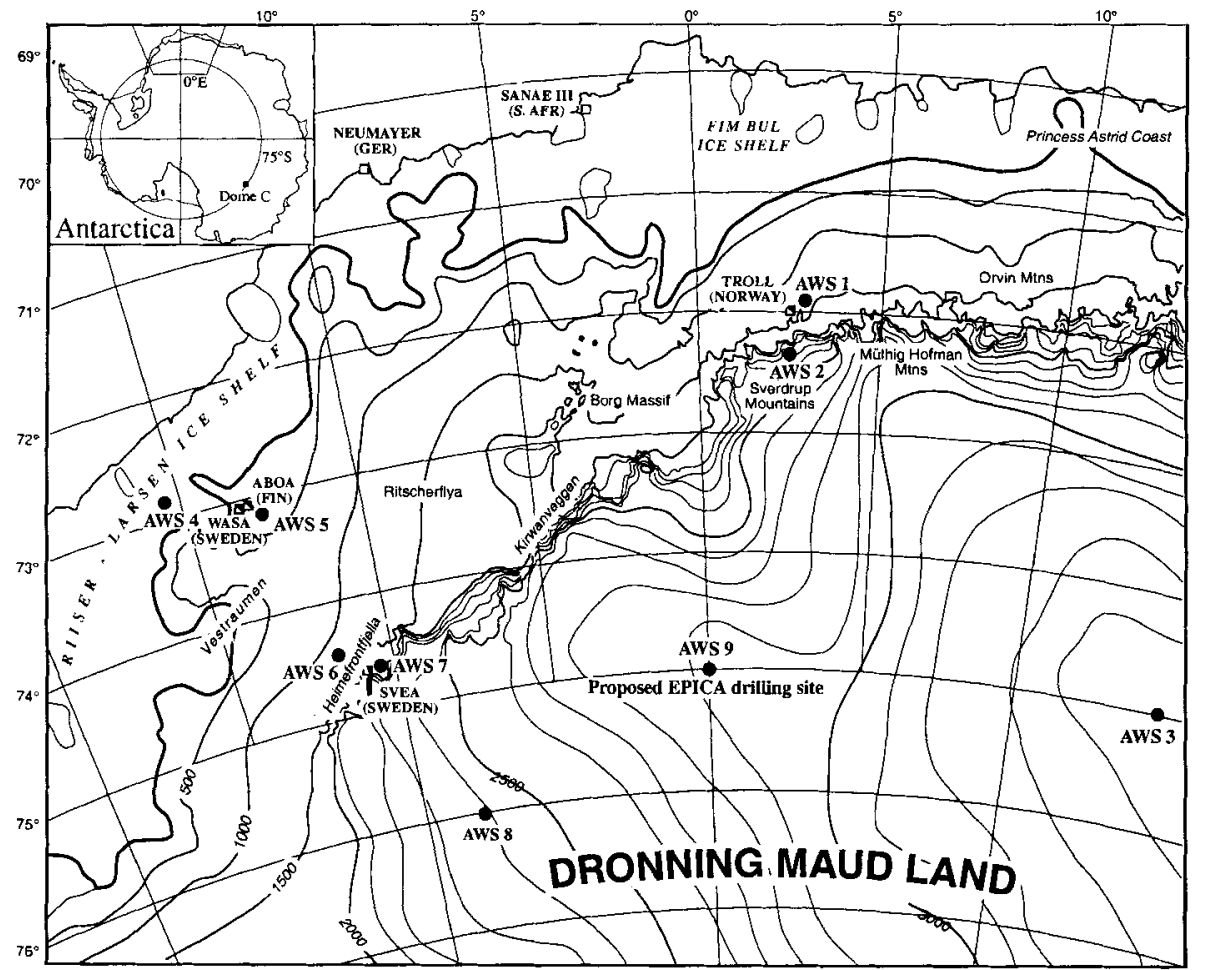

Fig. 1. Map of Dronning Maud Land, Antarctica, showing the locations of the Automatic Weather Stations. AWS 9 is situated at the suggested location of the EPICA drilling site.
Weather Forecasts (ECMWF) reanalysis to describe the seasonal patterns and trajectories of significant snowfall in the Dronning Maud Land region. However, Noone et al. (1999) concentrate on the general characteristics of major events while the focus in this paper is on the source regions of the moisture.

In the next section we briefly describe the weather stations and in the following section the trajectory model. Then, a oneyear record of AWS accumulation is analysed and compared with ECMWF modelled snowfall. Using the wind fields of the ECMWF model, backward air parcel trajectories are computed and described to assess moisture source regions of the snow in 1998. A high accumulation event in May 1998 is described in more detail in a later section.

\section{The Automatic Weather Stations}

At present, the Institute for Marine and Atmospheric Research Utrecht (IMAU) operates nine Automatic Weather Stations in Dronning Maud Land, Antarctica (Fig. 1). AWS 1 to 3 were installed in January 1997 along a traverse line connecting the Norwegian research station Troll to the Antarctic plateau (van den Broeke et al. 1999). AWS 4 to 9 were installed in the austral summer of 1997-98 on a transect ranging from the coast along the Swedish research stations Wasa and Svea to the plateau (Holmlund et al. 2000). AWS 9 was placed at the planned location of the EPICA drilling site in DML.

The AWS measure air temperature, wind speed, wind direction, instrument height, air pressure, firn temperature (except AWS 2) and downward directed short-wave radiation.
AWS 4 to 9 additionally measure relative humidity, upward directed shortwave radiation and upward and downward directed long wave radiation. The sampling rate is six (AWS 1 to 3 ) and five (AWS 4 to 9) minutes. Hourly (AWS 1 to 3 ) and two hourly (AWS 4 to 9) averages are stored and transmitted via Argos satellites. The instrument height is measured using a sonic height sensor. The changes in instrument height are a measure for the amount of accumulation in metres of snow. The initial height of the instruments was about $3 \mathrm{~m}$ above the surface. In this study we focus on AWS 8 and 9.

\section{The trajectory model}

We use the Royal Netherlands Meteorological Institute (KNMI) trajectory model (Scheele et al. 1996) to calculate air parcel backward trajectories. This model computes the threedimensional displacement of an air parcel during a time step $\Delta t$ using an iterative scheme:

$$
\mathbf{X}_{n+1}=\mathbf{X}_{0}+\frac{\Delta t}{2}\left[\mathbf{v}\left(\mathbf{X}_{0}, t\right)+\mathbf{v}\left(\mathbf{X}_{n}, t+\Delta t\right)\right] .
$$

In this equation $\Delta t$ is the iteration time step, $X_{0}$ is the position vector of the parcel at time $t, \mathrm{X}_{\mathrm{n}}$ is the $n^{\text {th }}$ iterative approximation of the position vector at time $t+\Delta t$ and $\mathbf{v}(\mathbf{X}, t)$ is the wind vector at position $\mathbf{X}$ and time $t$. The iteration time step is $10 \mathrm{~min}$. The iteration stops when the horizontal distance between $\mathbf{X}_{n}$ and $\mathbf{X}_{n+1}$ is less than $300 \mathrm{~m}$ and the relative vertical (pressure) difference is less than 0.0001 . The model is able to compute different types of trajectories e.g. isentropic, isobaric or three-dimensional. The latter is used 
because it most accurately approximates the true threedimensional transport path (Stohl et al. 1995, Kottmeier \& Fay 1998).

We use output from the ECMWF operational Numerical Weather Prediction (NWP) model as input for the trajectory model. The wind fields are first guess fields, not analyses, to ensure physical balance in the meteorological fields, which assures accurate representation of the vertical wind speed component. Note that in 1998 the orography in the ECMWF model was improved and the resolution changed from T213 (about $0.8^{\circ}$ ) to $\mathrm{T} 319$ (about $0.6^{\circ}$ ). For the trajectory model, the resolution of the input data is kept constant at $1.5^{\circ}$ in the horizontal plane, 31 levels in the vertical and six hours in time. This makes interpolation in time and space necessary. The spatial interpolation is bilinear in the horizontal and linear with $\log$ (pressure) in the vertical. The time interpolation is quadratic.

Uncertainties introduced by the choice of trajectory type and interpolation schemes are of the order of $1000 \mathrm{~km}$ after five days calculation (Kahl et al. 1989, Stohl et al. 1995). Errors in the vertical wind component are a major source of uncertainties in the calculated trajectories. This implies that the usefulness of identifying source regions after five days is limited to areas with horizontal dimensions on the order of $1000 \mathrm{~km}$, about nine degrees latitude. In reality, the uncertainty might be larger because of the difference between the first guess wind fields and the real winds, and the presence of convective systems (e.g. fronts, convective storms). In a

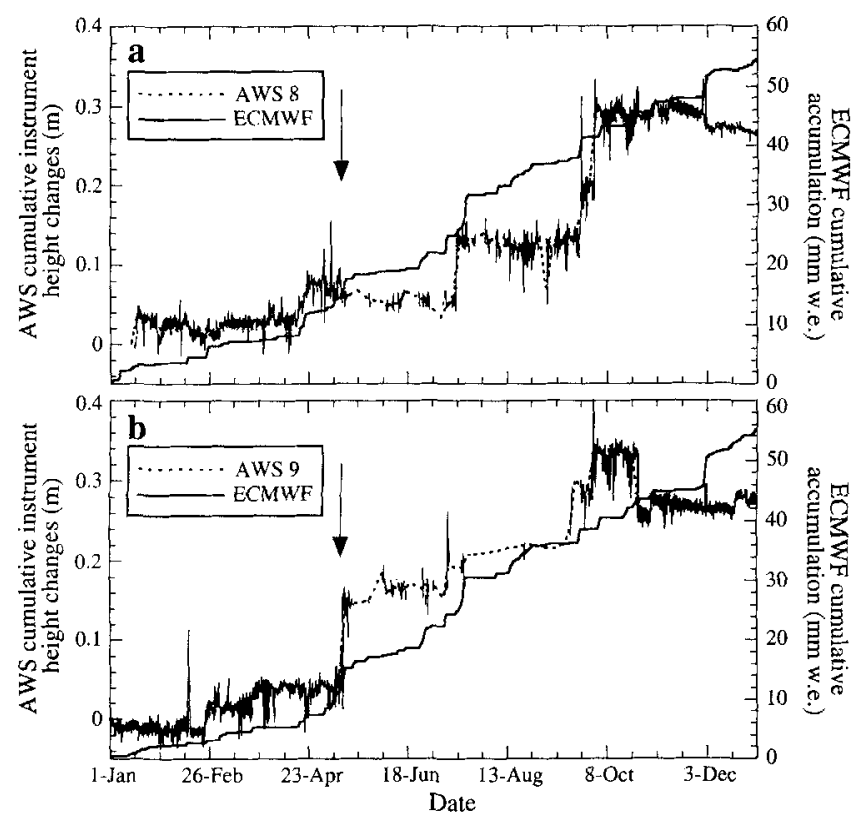

Fig. 2. Accumulation as a function of time at a. AWS 8 and $\mathbf{b}$. AWS 9 for 1998. The left scale shows the cumulative instrument height changes measured at the AWS sites. The right scale shows the ECMWF cumulative snowfall at the AWS grid points in $\mathrm{mm}$ w.e. The arrows indicate the snowfall event in May 1998 convective system the air parcel loses its identity making it impossible to trace a single parcel deterministically. This important source of errors in trajectories is difficult to assess and is not quantified in the uncertainty estimate. Fortunately, precipitation in the polar atmosphere is generally stratiform and convective mixing will be small. Kahl et al. (1989) conclude that sensitivity due to differences in gridded meteorological data bases, an indicator for errors in wind fields, can be larger than the sensitivity due to different trajectory calculation methods. So, computed trajectories must be interpreted with care.

\section{Model and measurement comparison}

In the following analysis a distinction is made between trajectories with and without snowfall on arrival at the AWS sites. To investigate the ability of the ECMWF model to correctly analyse meteorological parameters at the AWS sites, the ECMWF data at the $75.0^{\circ} \mathrm{S}, 0.0^{\circ} \mathrm{E}$ grid point are compared with measurements from two stations on the higher plateau, AWS 8 and 9. The other stations are either too close to large orographic gradients and therefore subject to large uncertainties in the first guess fields or suffer from lack of data. As such, they are not included in this analysis. Model snowfall is based on the cumulative snowfall in the first 12 forecast hours and suffers from model spin-up. Snowfall from the 0 to 12 hours forecast is about $9 \%$ less than the amount from the 12 to 24 hours forecast (Turner et al. 1999).

In general, the meteorological parameters such as pressure, temperature, wind speed and wind direction are reasonably well reproduced by the ECMWF model, especially after the resolution and orographic improvements. The AWS measurements show that most accumulation occurs in about four major events per year contributing about $80 \%$ to the total annual accumulation (Fig. 2). It is difficult to quantitatively verify the snowfall in the ECMWF model using AWS observations as they are very different types of data. The AWS measures instrument height, which includes processes such as snowfall, snowdrift, sublimation, deposition and densification of the snow pack. In case of accumulation, it is difficult to assess how much and when the accumulation is snowfall or snowdrift. Furthermore, the model precipitation represents the mean precipitation rate over the area of a grid cell rather than one location within the cell.

If we assume mean densities of $450 \mathrm{~g} \mathrm{~kg}^{-1}$ (L. Karlöf, personal communication 1999) and $335 \mathrm{~g} \mathrm{~kg}^{-1}$ (H. Oerter, personal communication 2000) at AWS 8 and 9, respectively, then an annual accumulation results of about $116 \mathrm{~mm}$ w.e. at AWS 8 and about $91 \mathrm{~mm}$ w.e. at AWS 9. The ECMWF snowfall in 1998 was about $55 \mathrm{~mm}$ w.e. at both sites. The ECMWF accumulation is lower compared to both AWS values. Noone et al. (1999) compared cumulative accumulation measured by a thermistor $\left(77^{\circ} \mathrm{S}, 10^{\circ} \mathrm{W}\right)$ with ECMWF model precipitation, and found an overestimation of the accumulation in the model. Precipitation in the coastal 
areas of Antarctica is often orographicaly induced (Bromwich 1988). Errors in the model orography could therefore have great influence on the amount and location of model snowfall. Genthon \& Braun (1995) show that the ECMWF orography (improved in 1998) was about $1000 \mathrm{~m}$ too high in DML resulting in too little precipitation on the Antarctic plateau in this area (Turner et al. 1999). This explains part of the found difference at AWS 8 and 9 but does not explain the overestimation found by Noone $e t$ al. (1999). Differences are also explained by the difficulty to distinguish snowfall from snowdrift from the AWS data and the fact that the model snowfall represents the mean of a grid cell rather than one location within the cell. The difference suggest that the precipitation is not uniformly distributed in a model grid cell.

From medium deep ice cores and snow pits the mean accumulation near AWS 8 was estimated to be about $62 \mathrm{~mm}$ w.e. $\mathrm{yr}^{-1}$ over the last 182 years (Karlöf et al. 2000) and about $62 \mathrm{~mm}$ w.e. $\mathrm{yr}^{-1}$ over the last 200 years at AWS 9 (Oerter et al. 2000). The ECMWF snowfall in 1998 ( $55 \mathrm{~mm} \mathrm{w.e.)} \mathrm{is} \mathrm{similar}$ to these estimates. The model seems to reflect better the mean conditions at a site rather than actually capturing a high accumulation year. In 1999 the annual accumulation at AWS 8 and 9 was lower, $62 \mathrm{~mm}$ w.e. and $81 \mathrm{~mm}$ w.e., respectively. The high accumulation values in 1998 can be explained by the fact that in 1997-98 a strong El Niño was observed. Jones \& Simmonds (1993) showed for the 1982-83 and 1986-87 El Niño events that winter cyclones are more intense. This results in a greater than normal advection of heat and moisture in DML and possible higher accumulation. Measurements at Halley, the British research station on the Brunt ice shelf, and at Neumayer, the German research station on the Ekström ice shelf, show that the temperature and wind speed in 1998 were about average. The mean pressure was lower than average, which indicate larger than average depression activity in 1998.

Figure 2 compares AWS instrument height measurements at AWS 8 and 9 with ECMWF snowfall at those locations for 1998. The individual events are not well correlated. For example, in May 1998 a major snowfall event was recorded at AWS 9 and not at AWS 8. The ECMWF model shows snowfall at both stations for that event. The discrepancies are due to model limitations. The model gives regional scale results, not local. Note that there is no apparent seasonality in the timing of the snowfall events.

\section{Trajectories in 1998}

Trajectory calculations are initiated (and air parcels arrive) every 12 hours ( $0.00 \mathrm{GMT}$ and $12.00 \mathrm{GMT})$ at six different pressure levels above the surface with starting point $75.0^{\circ} \mathrm{S}$, $0.01^{\circ} \mathrm{E}$ (AWS 9). Trajectories that intersect the surface are omitted from the analysis (about $9 \%$ of the trajectories). We make distinction between cases with and without snowfall at arrival, based on ECMWF snowfall. To mark a trajectory as a snowfall trajectory, at least $0.5 \mathrm{~mm}$ w.e. of snow must have accumulated in the 12 hours preceding the parcel arrival. For 1998, this resulted in 23 events at AWS 9, which represents about $37 \%$ of the total ECMWF model accumulation.

Figure 3a presents the mean of all trajectories and Fig. 4a the mean of snowfall trajectories, arriving at AWS 9 at different altitudes. Both show a cyclonic curve reflecting the substantial influence of cyclones on the air parcel paths in Antarctic coastal regions. Due to the higher wind speeds at higher altitudes, the distance travelled by air parcels arriving at higher altitudes is larger and their origin is further to the west. There is no clear seasonal shift in curve or direction of the trajectories due to e.g. the semi-annual oscillation (SAO). In 1998, the SAO is weakly developed in this area. SAO and the influence of SAO on the Antarctic climate are more extensively described in e.g. van Loon (1972) and van den Broeke (2000). Trajectories for AWS 8 (not shown) are similar but shifted towards the west. Noone et al. (1999)

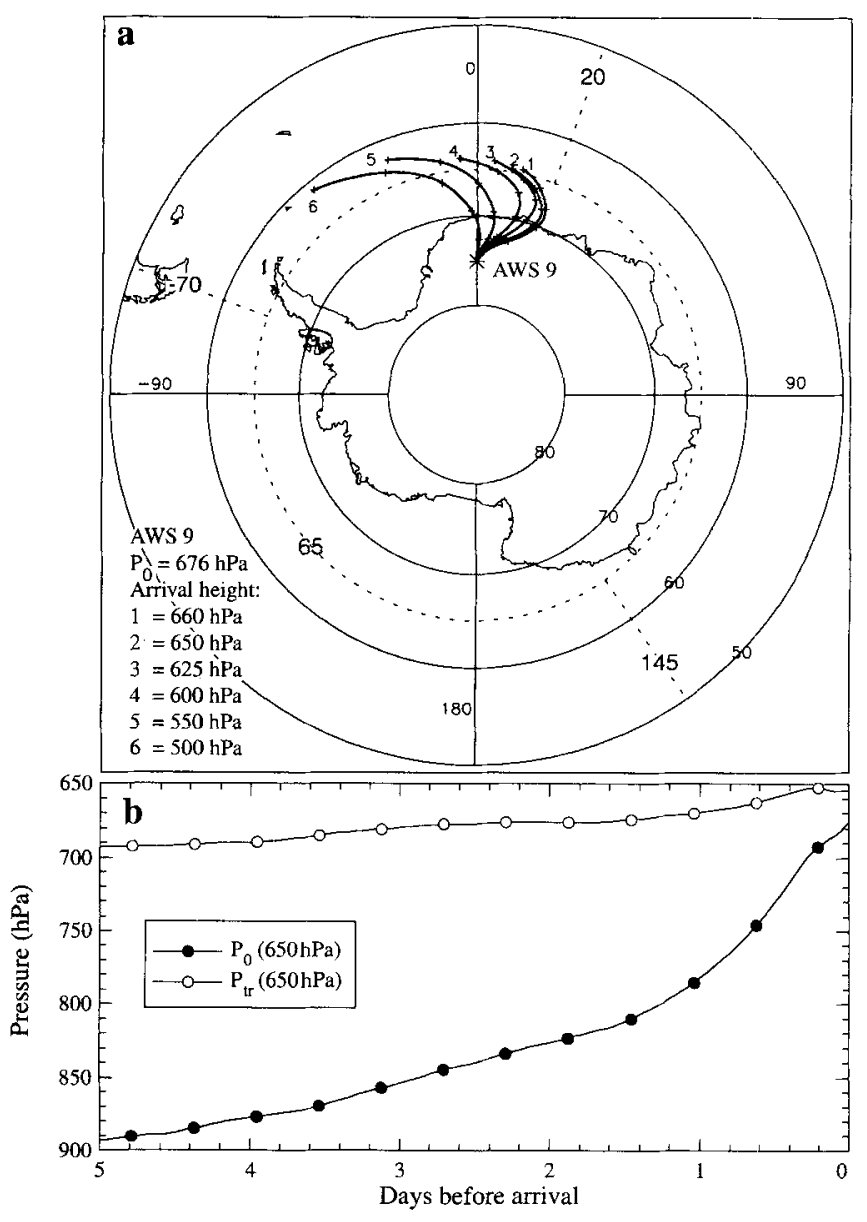

Fig. 3. a. Mean five days backward trajectories arriving at AWS 9, starting at six different pressure levels above the surface. Each day back is marked with a plus sign. The cross indicates the position of AWS 9 and the dotted lines indicate the boundaries of source regions defined in the text. $b$. Mean vertical displacement in pressure of all trajectories arriving at $650 \mathrm{hPa}$. $P_{0}$ is the mean surface pressure, $P_{t r}$ the mean trajectory pressure. 

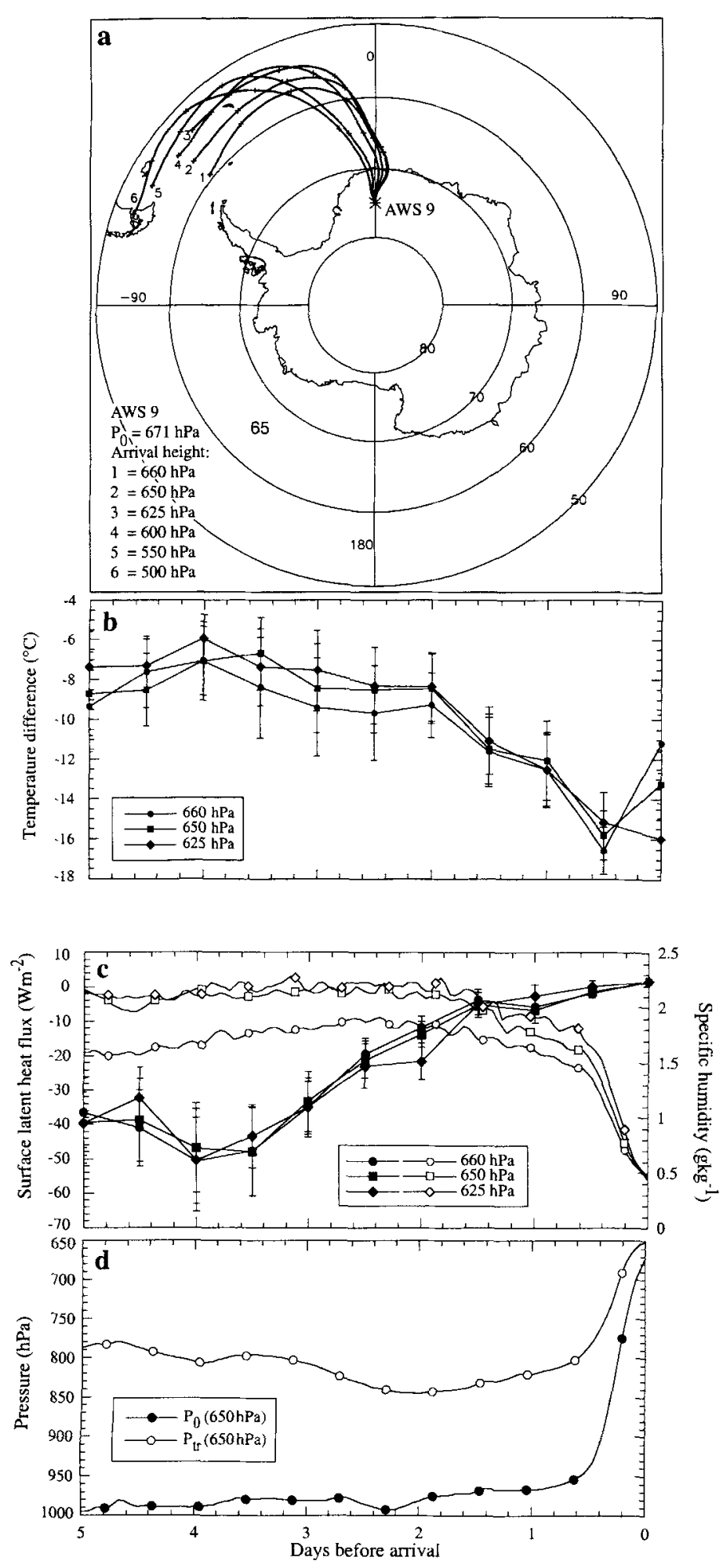

examines the mean poleward moisture flux in the sector $10^{\circ} \mathrm{W}$ to $15^{\circ} \mathrm{E}$ to study the general approach direction of the moisture. In agreement with our results they find that the moisture approaches from the north-east.

Figures $3 b$ \& $4 d$ present the pressure level of the mean trajectories and mean snowfall trajectories, respectively, arriving at $650 \mathrm{hPa}$ at AWS 9 , about $20 \mathrm{hPa}$ above the surface within the maximum in the poleward moisture transport found by Noone et al. (1999). On average, snowfall trajectories are situated at higher pressure levels and have higher surface pressures along their path because they travel closer to sea level. The non-snowfall trajectories remain longer over the continent, which is reflected in the lower surface and trajectory pressure. Figures $3 \& 4$ show that snowfall and non-snowfall trajectories are quite different in character. Because only snowfall trajectories will contribute to the accumulation and therefore be reflected in an ice core, care must be taken only to consider those trajectories that contribute to the accumulation to obtain an unbiased assessment of the recorded climate signal.

The maritime nature of snowfall trajectories is alsoillustrated in Fig. 5, which shows the percentage of trajectories located in a certain region. To define these regions, the Southern Hemisphere is divided into five regions: the Atlantic Ocean $\left(70^{\circ} \mathrm{W}-20^{\circ} \mathrm{E}\right)$, the Indian Ocean $\left(20^{\circ} \mathrm{E}-145^{\circ} \mathrm{E}\right)$, the Pacific Ocean $\left(145^{\circ} \mathrm{E}-70^{\circ} \mathrm{W}\right)$, the Southern Ocean (between the Antarctic continental boundaries and $65^{\circ} \mathrm{S}$ ) and the Antarctic continent. The trajectories in this figure have their arrival height within the boundary layer at $650 \mathrm{hPa}$, about $20 \mathrm{hPa}$ above the surface at AWS 9 . Figure $5 \mathrm{~b}$ shows that one day before arrival most snowfall parcels $(60 \%)$ are in the Southern (Atlantic) Ocean or in the Atlantic Ocean (25\%). In days 2 to 4 before arrival, 70 to $80 \%$ of the parcels are in the Atlantic Ocean. Five days before arrival, $30 \%$ of the parcels are in the Pacific Ocean. Delaygue et al. (2000) suggested a larger contribution from the Indian Ocean, 5-15\% compared to $0-5 \%$ in our results. This is partly due to the size of their grid box $\left(10^{\circ} \times 2^{\circ}\right)$ and the displacement of their DML grid box towards the south and east of our point $\left(75-77^{\circ} \mathrm{S}, 0-10^{\circ} \mathrm{E}\right)$. The contribution of the Southern Ocean calculated by Delaygue et al. (2000) is of the same order of magnitude (about $15 \%$ ), but the contribution of the Pacific Ocean is much larger, $20-30 \%$ compared to $0-5 \%$ in Fig. 5 . The contribution of the

Fig. 4. a. As Fig. 3a but only trajectories with snowfall at arrival at AWS 9 are taken into account. b. Mean temperature difference (surface temperature-potential temperature) along the snowfall trajectories. c. Surface latent heat flux (LE) averaged over all snowfall trajectories (closed symbols, left scale) and mean specific humidity at trajectory level (open symbols, right scale). LE is defined negative when directed away from the surface. In $b \& \mathrm{c}$, error bars indicate $1 \mathrm{~s} \mathrm{~d}$ from the mean. $d$. Mean vertical displacement in pressure of the snowfall trajectories arriving at $650 \mathrm{hPa} . \mathrm{P}_{0}$ is the mean surface pressure, $P_{t r}$ the mean trajectory pressure. 
Atlantic Ocean is the most important in both studies, but the amounts differ, $35-60 \%$ compared to $40-80 \%$ in our results. In this analysis the assumption is made that all moisture in the air parcel originates from somewhere along the 5-day trajectories. Taking the moisture already in the parcel into account, the contribution of the Pacific Ocean will probably increase due to the mean westerly flow, and the contribution from the Atlantic Ocean decrease. The results would then better resemble the results of Delaygue et al. (2000).

When the snowfall criterion is changed to $0.25 \mathrm{~mm}$ w.e. of snow in the 12 hours preceding the parcel arrival, 73 events (68.7\% of the accumulation) are taken into account. The contribution of the Atlantic Ocean decreases to $40-50 \%$, $2-5$ days before arrival (not shown). The contributions of the Southern Ocean and the Continent, trajectories remaining close to or on the continent, increase with about $10 \%$ on each day before arrival. Taking all snowfall events into account (223 events, not shown) decreases the contribution of the Atlantic Ocean even further to $30-40 \%$ and increases the percentage of trajectories remaining over the continent to about $40 \%$. When all trajectories are taken into account results are completely different (Fig. 5a). The majority of the parcels now originate from the continent, about $20 \%$ remains fairly close to the continent in the Southern Ocean, 10 to $20 \%$ comes from the Atlantic Ocean and the rest from the Indian Ocean. Almost none originates from the Pacific Ocean.

Figure 6 shows the position of all trajectories four days before arrival at $75.0^{\circ} \mathrm{S}, 0.01^{\circ} \mathrm{E}$ at $650 \mathrm{hPa}$, in which the squares represent the positions of trajectories with more than $0.5 \mathrm{~mm}$ w.e. snowfall at arrival. The variations in both snowfall and non-snowfall points is significant and becomes larger when going further back in time and when the arrival height is higher. Almost all trajectories remain south of $40^{\circ} \mathrm{S}$ within the five days of trajectory calculation and none reaches farther north than $30^{\circ} \mathrm{S}$.

Assuming the origin of the moisture to be distributed along the five day snowfall trajectories, the source region of the moisture in DML is most likely the Atlantic Ocean (Fig. 5). To be able to specify the source region more precisely the specific humidity along the snowfall trajectories, the surface latent heat flux (LE) and the surface temperature underneath the snowfall trajectories are determined. Figure $4 \mathrm{c}$ displays LE and the specific humidity. LE shows a maximum about four days before arrival and increases (less evaporation) when going towards the Antarctic. The specific humidity slightly increases between 5 and 2.5 days before arrival. The mean trajectory height is about $200 \mathrm{hPa}$ above the surface and the mean difference in surface temperature and potential trajectory temperature is negative indicating stable conditions. When the temperature difference is negative and large in magnitude, vertical mixing is less likely and the air parcel is not likely to interact with the surface. It is therefore difficult to asses whether the parcels are in the boundary layer and able to interact with the surface. The temperature difference is smallest about four days before arrival which coincides with

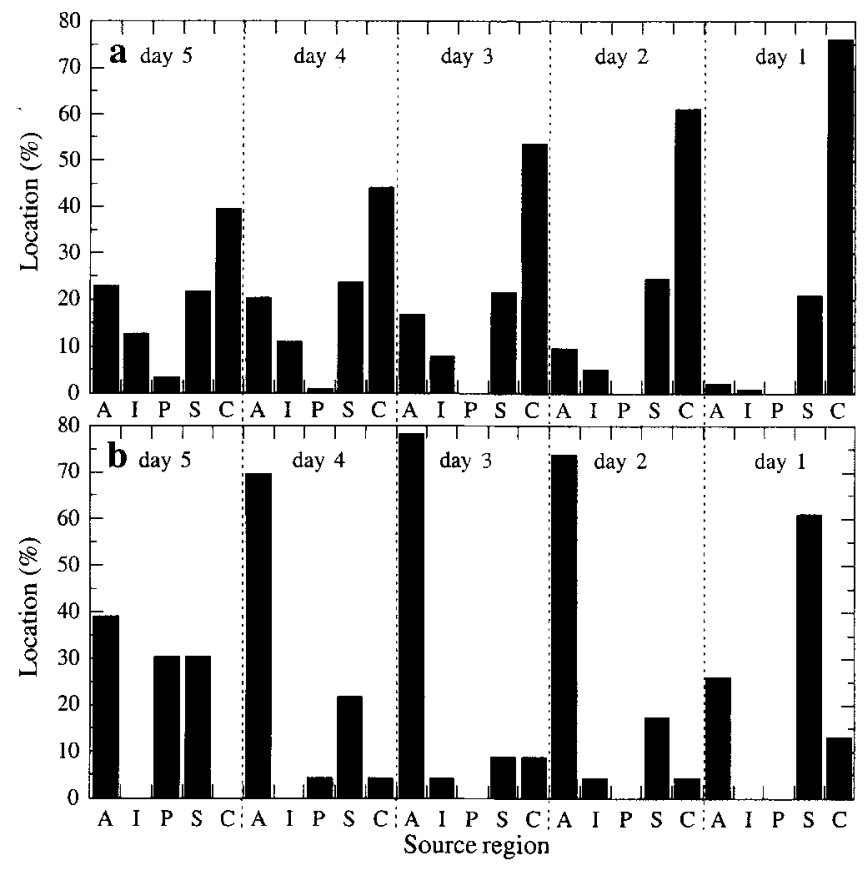

Fig. 5. Percentage of the backward trajectories, started at AWS 9, with their source region in one of the five regions defined in the text and Fig. 3. A = Atlantic Ocean, $\mathrm{I}=$ Indian Ocean, $\mathrm{P}=$ Pacific Ocean, $\mathrm{S}=$ Southern Ocean and $\mathrm{C}=$ Antarctic Continent. The arrival height of the trajectories is $650 \mathrm{hPa}$ a. All trajectories are taken into account. b. Only the trajectories with snowfall at AWS 9 are taken into account

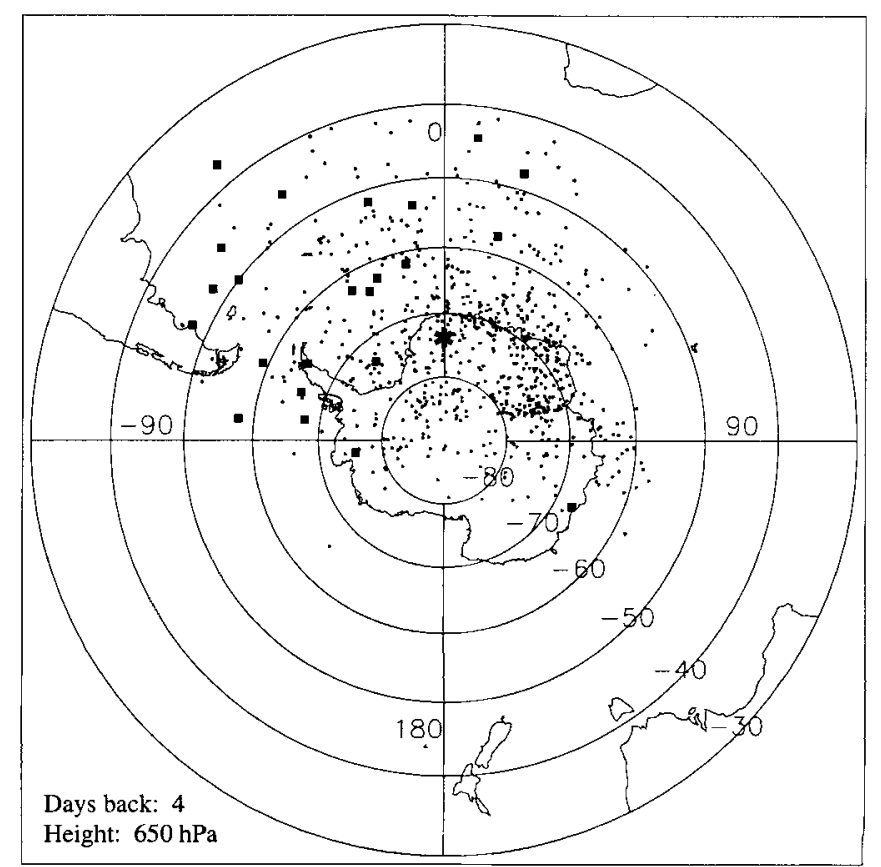

Fig. 6. Locations of all trajectories four days before arrival at AWS 9 at $650 \mathrm{hPa}$. The asterisk indicates the location of AWS 9, the squares are the positions of trajectories with more than $0.5 \mathrm{~mm}$ w.e. snowfall at arrival. 


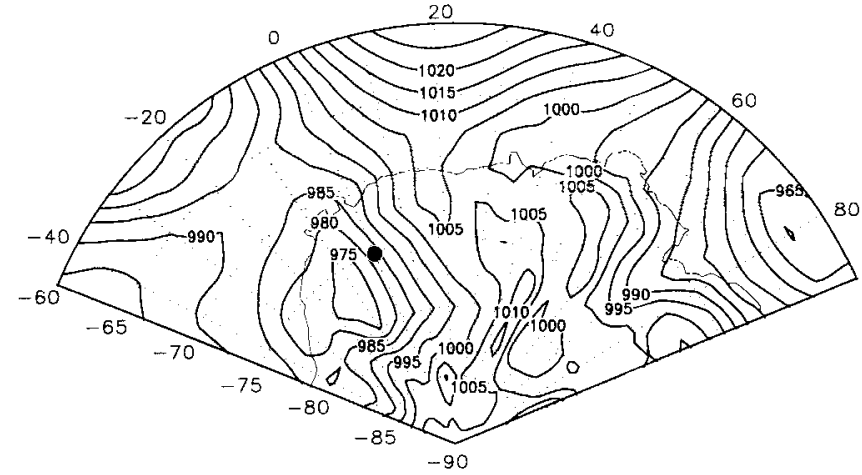

Fig. 7. Sea level pressure for 12 May 1998,0.00 GMT. The dot indicates the location of AWS 9.

the strongest evaporation (Fig. 4c) and a small increase in specific humidity. The largest snowfall events (with more than $1.0 \mathrm{~mm}$ w.e. in the 12 hours preceding arrival) have their 4-day origin between $40^{\circ}$ and $50^{\circ} \mathrm{S}$.

From our results it follows that the most likely source region of snow in DML is the Atlantic Ocean between about $40^{\circ}$ and $60^{\circ} \mathrm{S}$. This is at the southern edge of source regions defined by Petit et al. (1991) $\left(30-40^{\circ} \mathrm{S}\right)$ and Ciais et al. (1995) $\left(20-40^{\circ} \mathrm{S}\right)$ using deuterium excess as an indicator and Peixoto \& Oort (1992) based on atmospheric balance studies (8$40^{\circ} \mathrm{S}$ ). Our results are more in agreement with GCM studies which define source regions between $30^{\circ}$ and $60^{\circ} \mathrm{S}$ (Delaygue et al. 2000, Delmotte et al. 2000). Our source region is to the north and over warmer seas compared to oxygen isotope studies which define source regions between $55^{\circ}$ and $60^{\circ} \mathrm{S}$ with sea surface temperatures between $0^{\circ}$ and $1^{\circ} \mathrm{C}$ (Bromwich $\&$ Weaver 1983). Our source region has a wider meridional extend and sea surface temperatures may vary between $0^{\circ}$ and $20^{\circ} \mathrm{C}$.

\section{Case study: a major snowfall event in May 1998}

In 1998, about four major snowfall events took place (Fig. 2), that contributed about $80 \%$ of the total annual accumulation. The event in May 1998 was the most pronounced event, with accumulation at all AWS except 7 and 8, and also in the ECMWF analysis. In general, snowfall in western DML is associated with the development of a cyclone in the Weddell Sea area and a high-pressure ridge over eastern DML. The strong north-easterly flow connected to this ridge in combination with the steep orography of DML forces the air to rise and snowfall is generated. The event described here is

Fig. 8. Hourly mean (AWS) and 6-hourly variation (ECMWF) of a. temperature, b. specific humidity, c. wind speed, d. wind direction, e. pressure and f. accumulation at AWS 9 for the snowfall event in May 1998. Closed circles present AWS data, open circles present ECMWF surface values at the AWS location. $f$. the surface height is $0 \mathrm{~m}$ and the ECMWF accumulation is $0 \mathrm{~mm}$ w.e. at 1 January 1998.
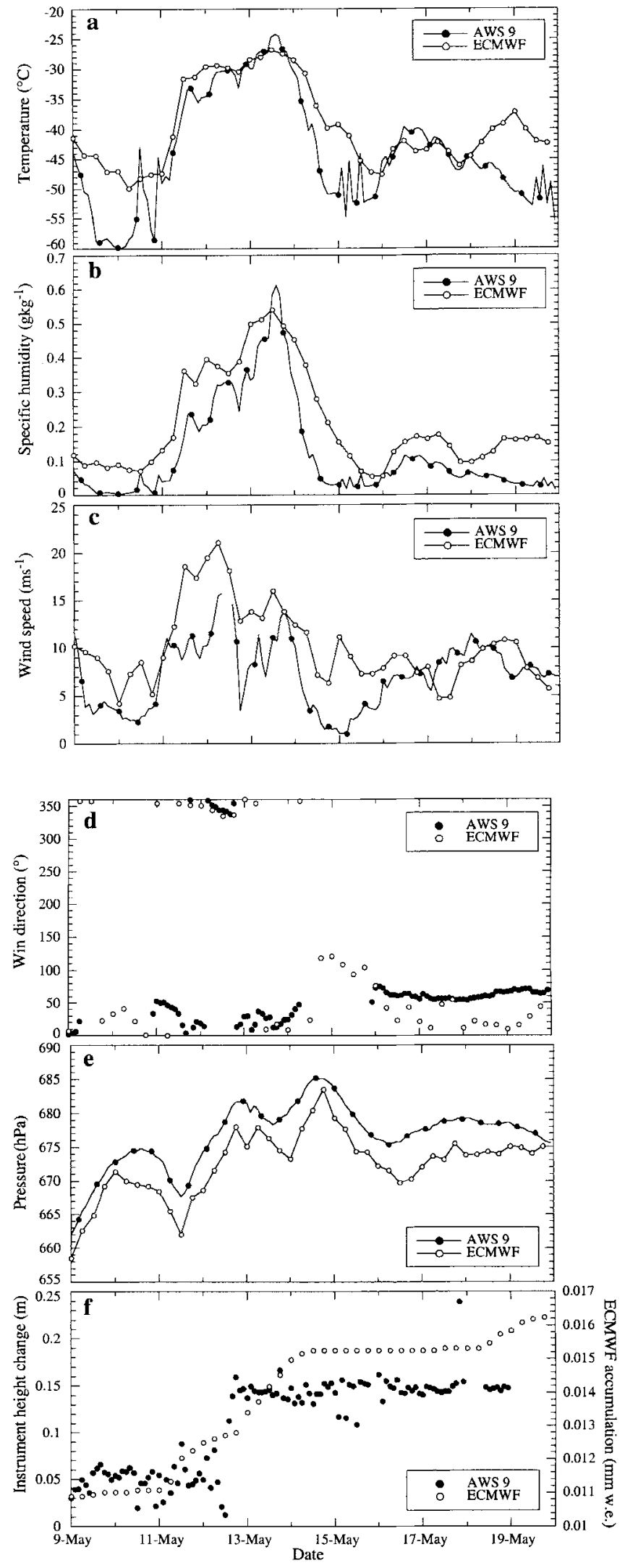
similar to the events described by Noone et al. (1999).

In May 1998, a significant amount of snow accumulated in DML varying from about $20 \mathrm{~mm}$ w.e. at AWS 1 and 4 to about $160 \mathrm{~mm}$ w.e. at AWS 2. The event started on 11May when a high pressure ridge extended sufficiently south to force depressions towards the continent and away from their climatological track, parallel to the coastline (see Fig. 7). From 11-14 May the northerly flow advects two depressions with warm and moist air south towards the continent. After 14 May the ridge moves east and breaks down rapidly.

Figure 8 shows the temperature, specific humidity, wind speed, wind direction, pressure and accumulation record measured at AWS 9 for 10 days in May containing the event. The mean temperature in May is about $-50^{\circ} \mathrm{C}$. The temperature during this event rapidly increases from $-60^{\circ} \mathrm{C}$ on 10 May to $-24^{\circ} \mathrm{C}$ on $13 \mathrm{May}$, which is exceptionally high. Simultaneously, the specific humidity increases from almost 0 to $0.8 \mathrm{~g} \mathrm{~kg}^{-1}$. The wind speed is also high, exceeding $15 \mathrm{~ms}^{-1}$ compared to a monthly mean of $6.6 \mathrm{~ms}^{-1}$. The wind direction changes from north-east $\left(50^{\circ}\right)$, the direction of the katabatic flow, to north $\left(0^{\circ}\right)$, in the direction of the large scale geostrophic flow. The pressure increases to a maximum of $685 \mathrm{hPa}$ showing the development of the high pressure ridge. The temporary dips in pressure at 11 and 13 May are caused by depressions. The surface height, a measure for accumulation, increases about $0.10 \mathrm{~m}$ at 12 May. Figure 8 additionally shows the ECMWF records at the AWS location. There is a good agreement between the records.

Figure 9 is an example of the ECMWF fields of the snowfall event at 13 May 1998, 12.00 GMT. Panel a shows that the snowfall is concentrated in an area along the coast from $20^{\circ} \mathrm{W}$ to $20^{\circ} \mathrm{E}$, parallel to the orography. All AWS are located in the area with snowfall except AWS 3. Panel b shows the height of the $500 \mathrm{hPa}$ level and the wind vectors at that same level illustrating the large scale flow. Clearly visible is the blocking high pressure ridge with its axis at $30^{\circ} \mathrm{E}$ and the strong northerly flow over western DML and the strong southerly flow over eastern DML. The warm air mass advected southwards can be identified in Figure $9 \mathrm{c}$ as a tongue of high temperatures spreading southwards along the coast. In eastern DML, where the flow is from the south, cold and dry continental air is advected northwards.

From 11-14 May the air at AWS 9 was saturated from the surface up to about $600 \mathrm{hPa}$ suggesting condensation in this area (Fig. 10). Backward trajectories were calculated for this event with the lowest three starting levels located within this layer. Figure 1 la shows trajectories arriving at 13 May 12.00 GMT at AWS 9. It shows that, independent of the arrival height at the AWS site, the transport pathway is the Atlantic Ocean. The difference between the surface temperature and potential temperature of the trajectory is smallest 4 days before arrival ( 9 May at 12.00) for the lowest three trajectories (Fig. 11b). At this day, the boundary layer is about $100 \mathrm{hPa}$ high topped by a saturated layer reaching the $750 \mathrm{hPa}$ level. The air parcels are in the saturated layer and probably able to interact with the surface. Surface evaporation along the lowest three trajectories is strongest 3-4 days before arrival (9-10 May). The specific humidity of the air parcels gradually increases during these days from about 0.5 to $3.5 \mathrm{~g} \mathrm{~kg}^{-1}$. The last two days before arrival the surface latent heat flux is positive (condensation/deposition) and the specific humidity of the air parcels decreases. This suggests that the moisture source region for this event is likely to be dominated by the area between $40^{\circ}$ and $50^{\circ} \mathrm{S}$ and $20^{\circ}$ and $60^{\circ} \mathrm{W}$, in the Atlantic Ocean. The sea surface temperature in this area is between 5 and $15^{\circ} \mathrm{C}$. The specific humidity record suggests that about $50 \%$ of the moisture arriving at AWS 9 originates from this region.
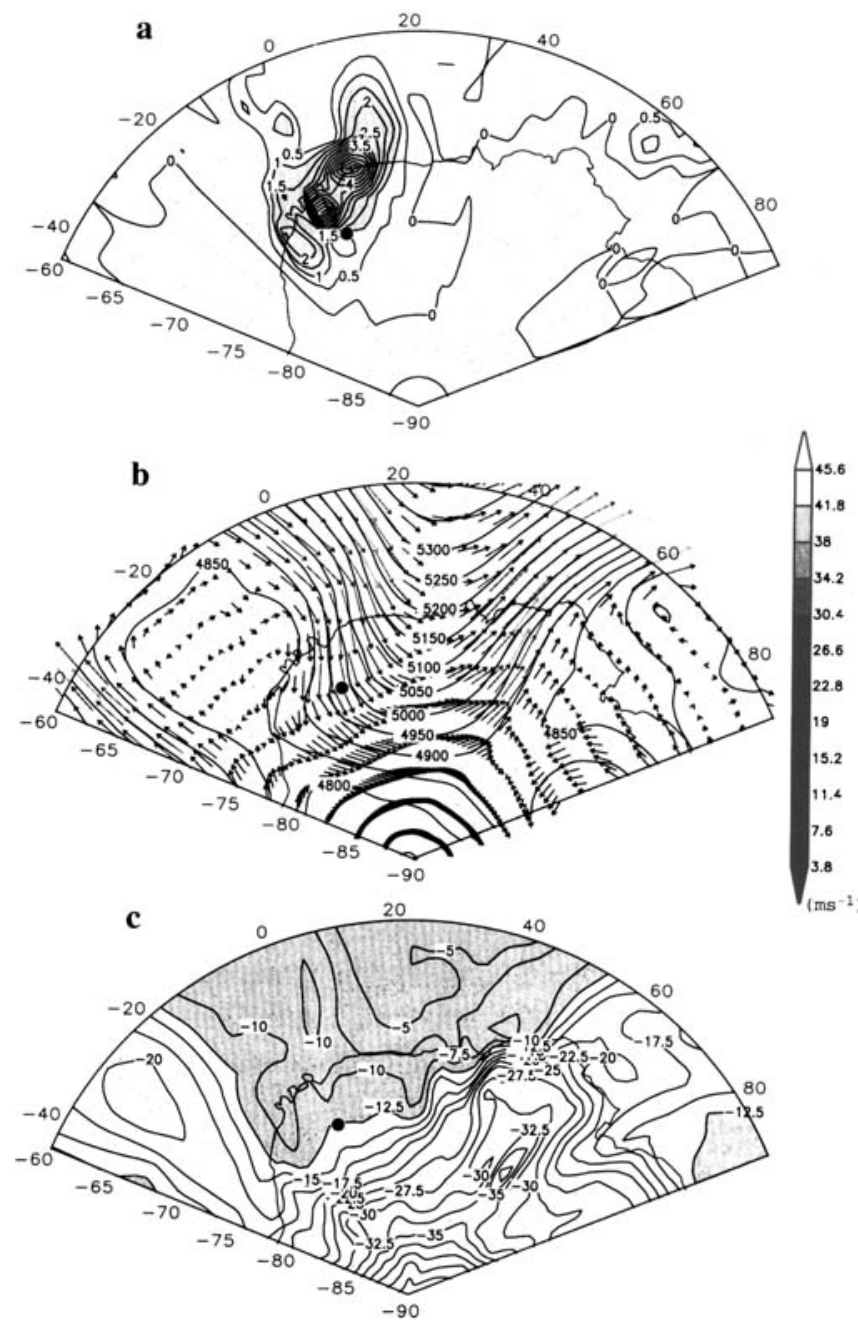

Fig. 9. ECMWF fields for 13 May 1998, 12.00 GMT a. Forecast snowfall in the previous 6 hours at the surface in $\mathrm{mm}$ w.e. b. Height of the $500 \mathrm{hPa}$ level in $\mathrm{m}$ plus the wind field in $\mathrm{ms}^{-1}$ at the same height. c. The temperature at $850 \mathrm{hPa}$, shaded values exceed $-12.5^{\circ} \mathrm{C}$. The dot indicates the location of AWS 9. (a. is a first guess field, b. \& c. are analyses fields.) 


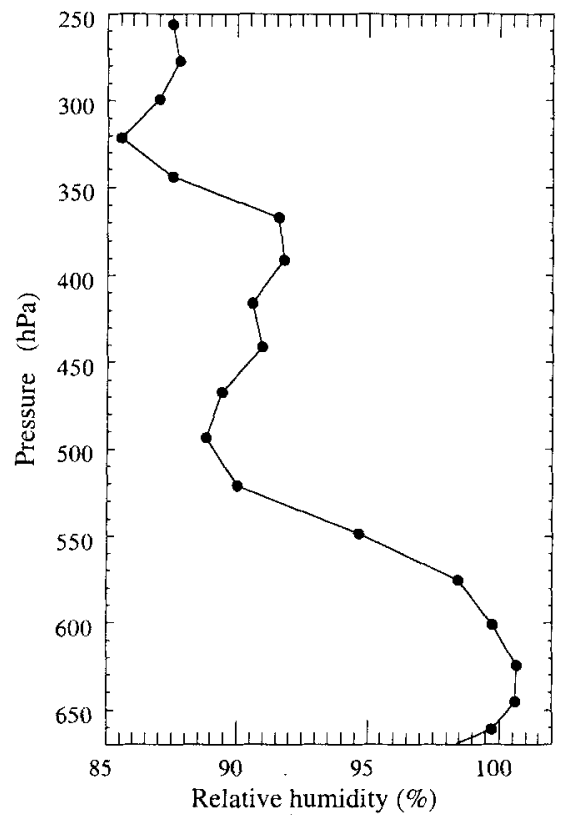

Fig. 10. Mean vertical profile from of the ECMWF model relative humidity at AWS 9 for the period 11-14 May 1998.

\section{Summary and conclusions}

In this paper we combined AWS data and trajectories to assess moisture sources for the snow accumulated on the plateau in Western Dronning Maud Land, Antarctica, in 1998. A distinction between snowfall and non-snowfall trajectories was made.

Substantial differences are found between accumulation measured at the AWS sites and ECMWF precipitation estimates. These differences are probably caused by the difficulty to distinguish precipitation from other processes in the measurements, errors in ECMWF model orography and the fact that model snowfall represents the mean of a grid cell rather than one location within the cell. The accumulation measurements did not show any seasonality. The record is at present too short and the number of events with substantial snowfall is too small (about four) to make any firm conclusions. However, the fact that the snowfall is not uniform or continuous over the year has significant implications for identifying annual layers in data from ice cores.

A case study of a snowfall event in May 1998 shows that snow falls during extreme weather conditions, which was also found by Noone et al. (1999). Trajectories calculated for this event show a source region of the moisture dominated by the western part of the Atlantic Ocean between $40^{\circ}$ and $50^{\circ} \mathrm{S}$ and $20^{\circ}$ and $60^{\circ} \mathrm{W}$.

Considering all the trajectories shows that about $40-80 \%$ of the snow that falls at AWS 9 in 1998 originates from the Atlantic Ocean, about $10 \%$ from the Pacific Ocean and almost none from the Indian Ocean. Based on trajectory height, temperature difference, the surface latent heat flux and the specific humidity, the origin of the moisture is most likely
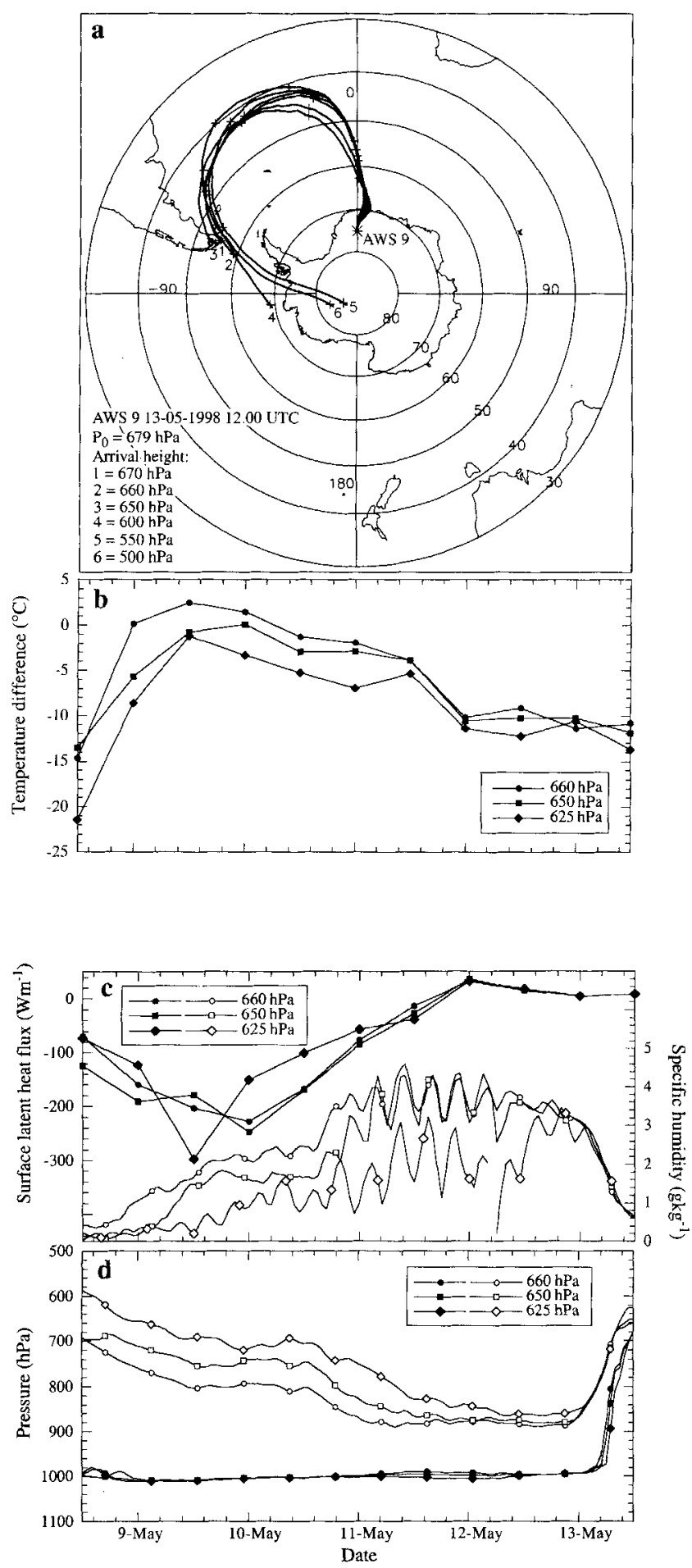

Fig. 11. a. Trajectories starting at AWS 9 for 13 May 1998, 12.00 GMT at six different levels five days back. b. Temperature difference (surface temperature-potential temperature) along the trajectory. c. Surface latent heat flux averaged over all snowfall trajectories (closed symbols, left scale) and mean specific humidity at trajectory level (open symbols, right scale). d. Mean vertical displacement in pressure of the snowfall trajectories, closed symbols are surface pressure, open symbols trajectory pressure. 
between $40^{\circ}$ and $60^{\circ} \mathrm{S}$ in the Atlantic ocean where sea surface temperatures vary between $0^{\circ}$ and $20^{\circ} \mathrm{C}$. This is in agreement with results from GCM studies (Delaygue et al. 2000, Delmotte et al. 2000).

Differences in source regions resulting from different studies do not necessarily contradict each other but could be the result of the different methods used. The advantage of GCMs is that moisture parcels are directly traced from evaporation point to precipitation point and simulations of other climates than the present are possible. A disadvantage is the use of climatologies and the coarse resolution (order of $10^{\circ}$ ) to enable long time integrations and the loss of information about the transport pathways. Deuterium excess and $\delta^{18} \mathrm{O}$ studies have the advantage to use the actual composition of the snow. However, the idealized models they use to determine the source regions, are not able to account for the complexity of atmospheric processes. Atmospheric water balance studies are the least suitable to determine source regions for Antarctic snow. They merely show large regions with a net evaporation or condensation surplus.

Air parcel trajectories have the advantage of using wind fields forced by observations with a fairly good resolution and air parcels are directly traced. A problem is that not the moisture itself but an air parcel containing moisture is followed: possible replacement of moisture through cycles of condensation and evaporation along the trajectory is not taken into account. The uncertainty in the trajectory calculations contributes significantly to the uncertainty in the identified moisture source region. The error estimates given in literature introduced by choice of trajectory type and interpolation schemes are of the order of $1000 \mathrm{~km}$ or $9^{\circ}$ (Kahl et al. 1989, Stohl et al. 1995) when calculating five days back. The actual uncertainty is even larger due to errors in the analysed wind fields and the presence of convective systems (e.g. fronts). In a convective system the air parcel loses its identity making it impossible to trace a single parcel deterministically. Calculation of an ensemble of trajectories can give an impression of the sensitivity of the trajectories to convective systems and changes in flow pattern. Because the different atmospheric conditions that lead to precipitation in DML are quite similar, the on year record of snowfall trajectories presented here can be considered to give an estimate of the variability one might expect over a longer period.

\section{Acknowledgements}

We thank Richard Bintanja, Henk Snellen, Martijn Thomassen and the other members of SWEDARP 1997-98 expedition to Svea and Wasa, the members of the German expeditions from the Alfred Wegener Institute, Bremerhaven, to Dronning Maud Land, especially Hans Oerter, and the members of the Norwegian traverse team of 1996-97 for their invaluable help with placing and servicing the Automatic Weather Stations in Dronning Maud Land. Furthermore we thank Peter Siegmund, Rinus Scheele, Erik van Meijgaard and Nicole van Lipzig from the KNMI for their help with the trajectory model. The two reviewers, Dr. R. Mulvaney and Dr. D. Noone, are thanked for their useful comments. Wind data was provided by the ECMWF. This is EPICA publication no. 24. This work is a contribution to the "European Project for Ice Coring in Antarctic" (EPICA), a joint ESF (European Science Foundation)/EC scientific programme, funded by the European Commission under the Environment and Climate Programme (1994-1998) contract ENV4-CT95-0074 and by national contributions from Belgium, Denmark, France, Germany, Italy, the Netherlands, Norway, Sweden, Switzerland and the United Kingdom.

\section{References}

Bromwich, D.H. 1988. Snowfall in high southern latitudes. Reviews of Geophysics, 26(1), 149-168.

BRomwich, D.H. \& WEAVER, C. 1983. Latitudinal displacement from main moisture source controls $\delta^{18} \mathrm{O}$ of snow in coastal Antarctica. Nature, 301, 145-147

Clais, P., White, J.W.C., Jouzel, J. \& Petir, J.R. 1995. The origin of present-day Antarctic precipitation from surface deuterium excess data. Journal of Geophysical Research, 100(D9), 18 917-18927.

Delaygue, G., Masson, V., Jouzel, J., Koster, R.D. \& Healy, R.J. 2000. The origin of Antarctic precipitation: a modelling approach Tellus, 52B, 19-36.

Delmotte, M., Masson, V. \& Jouzed, J. 2000. A seasonal deuterium excess signal at Law Dome, coastal eastern Antarctica: a southern ocean signature. Journal of Geophysical Research, 105(D6), 7187-7197.

Genthon, C. \& Braun, A. 1995. ECMWF analysis and predictions of the surface climate of Greenland and Antarctica. Journal of Climate, 8, 2324-2332.

Greenland ICe-Core Project (GRIP) Members. 1993. Climate instability during the last interglacial period recorded in the GRIP ice core. Nature, 364, 203-207.

Holmlund, P., Gierde, K., Gundestrup, N., Hansson, M., Isaksson, E., Karlof, L, Nyman, M., Pettersson, R., Pinglot, F., Reijmer, C.H., Stenberg, M., Thomassen, M., Van De Wal, R., Van Der Veen, C., WILHELMS, F. \& WINTHER, J.-G. 2000. Spatial gradients in snow layering and ten metre temperatures at two EPICA-DML pre site survey drill sites. Annals of Glaciology, 30, 13-19.

JonEs, D. A. \& Simmonds, I. 1993. A climatology of southern hemisphere extratropical cyclones. Climate Dynamics, 9, 131-145.

Jouzel, J., Alley, R.B., Cuffey, M., Dansgaard, W., Grootes, P., Hoffmann, G., Johnsen, S.J., Koster, R.D., Peel, D., Shuman, C.A., Stievenard, M., Stuiver, M. \& White, J. 1997. Validity of the temperature reconstruction from water isotopes in ice cores. Journal of Geophysical Research, 102(C12), 26 471-26 487.

KAhL, J.D., HarRis, J.M. \& HERBERT, G.A. 1989. Intercomparison of three long-range trajectory models applied to Arctic haze. Tellus, 41B, 524-536.

Karlof, L., Winther, J.-G., Isaksson, E., Kohler, J., Pinglot, J.F., Wilhelms, F., Hansson, M., Holmlund, P., Nyman, M., Pettersson, R., Stenderg, M., Thomassen, M. P.A., Van Der Veen, C. \& Van Der WAL, R.S.W. 2000. A 1500 year record of accumulation at Amundsenisen western Dronning Maud Land, Antarctica, derived from electrical and radioactive measurements on a $120 \mathrm{~m}$ ice core. Journal of Geophysical Research, 105(D10), 12 471-12 483.

Kottmeier, C. \& FAY, B. 1998. Trajectories in the Antarctic lower troposphere. Journal of Geophysical Research, 103(D9), $10947-10959$. 
NooNE, D. \& Simmonds, I. 1998. Implications for the interpretation of ice-core isotope data from analysis of modelled Antarctic precipitation. Annals of Glaciology, 27, 398-402.

Noone, D., Turner, J. \& Mulvaney, R. 1999. Atmospheric signals and characteristics of accumulation in Dronning Maud Land, Antarctica. Journal of Geophysical Research, 104(D16), 19 191-19 212.

Oerter, H., Wilhelms, F., Juno-Rothenhausler, F., Goktas, F., Miller, H., GraF, W. \& SOMmer, S. 2000. Accumulation rates in Dronning Maud Land as revealed by DEP measurements at shallow firn cores. Annals of Glaciology, 30, 27-34.

Peixoto, I.P. \& OORT, A.H. 1992. Physics of Climate. New York: American Institute of Physics, $520 \mathrm{pp}$.

Petit, J.R., White, J.W.C., Young, N.W., Jouzel, J. \& Korotkevich, Y.S. 1991. Deuterium excess in recent Antarctic snow. Journal of Geophysical Research, 96(D3), 5113-5122.

Petit, J.R., Raynaud, J.J.D., Barkov, N.I., Barnola, J.M., Basile, I., Benders, M., Chappellaz, J., Davis, M., Delaygue, G., Delmotte, M., Kotlyakov, V.M., Legrand, M., Lipenkov, V.Y., Lorius, C., Pepin, L., Ritz, C., Saltzman, E. \& Stievenard, M. 1999. Climate and atmospheric history of the past 420,000 years from the Vostok ice core, Antarctica. Nature, 399, 429-436.
Scheele, M.P., Siegmund, P.C. \& VAn Velthoven, P.F.J. 1996 Sensitivity of trajectories to data resolution and its dependence on the starting point: in or outside a tropopause fold. Meteorological Applications, 3, 267-273.

STOCKER, T.F. 1999. Past and future reorganizations in the climate system. Quaternary Science Reviews, 19, 301-319.

Stohl, A., Wotawa, G., Siebert, P. \& Kromp-Kolb, H. 1995. Interpolation errors in wind fields as a function of spatial and temporal resolution and their impact on different types of kinematic trajectories. Journal of Applied Meteorology, 34, 2149-2165.

Turner, J., Connelley, W.M., Leonard, S., Marshall, G.J.\& Vaughan, D.G. 1999. Spatial and temporal variability of net snow accumulation over the Antarctic from ECMWF re-analysis project data. International Joutrnal of Climatology, 19, 697-724.

VAN DEN BRoEKE, M.R. 2000. The semi-annual oscillation and Antarctic climate. Part 5: impact on the annual temperature cycle as derived from ncep/ncar re-analysis. Climate Dynamics, 16, 369-377.

van den Broeke, M.R., Winther, J.-G., Isaksson, E., Pinglot, J.F., Karlof, L., Eiken, T. \& ConRads, L. 1999. Climate variables along a traverse line in Dronning Maud Land, East Antarctica. Journal of Glaciology, 45(150), 295-302.

van Loon, H. 1972. Pressure in the southern hemisphere. American Meteorological Society, Meteorological Monographs, 13(35), 59-86. 